\title{
Karakter Morfologi dan Identifikasi Molekuler dengan Menggunakan Marka Gen 12S rRNA pada Ikan Baronang (Siganus spp.) di Perairan Laut Selatan Pulau Lombok
}

\section{Morphological and Molecular Characters Identification with a Marker of $12 S$ rRNA Gene in Rabbitfishes (Siganus spp.) at the Southern Sea Waters of Lombok Island}

\author{
Mahrus*, Abdul Syukur \\ Progran Studi Pendidikan Biologi PMIPA FKIP Universitas Mataram, \\ Jl. Majapahit 62 Mataram 83125, Telp. (0370) 646506 Indonesia \\ *corresponding author, email: mahrus@unram.ac.id
}

Manuscript received: 02-05-2020. Accepted: 09-06-2020

\begin{abstract}
ABSTRAK
Penelitian ini bertujuan untuk mendapatkan kepastian jumlah spesies ikan baronang (Siganus spp.) famili Siganidae di perairan laut selatan Pulau Lombok. Penelitian ini menggunakan sampel 90 ekor ikan dari hasil tangkapan nelayan. Pengambilan sampel menggunakan metode acak sebanyak tiga kali. Pengamatan karakter morfologi menggunakan 90 dan sembilan ikan untuk karakter molekuler-12S rRNA gen. Penelitian ini menggunakan teknik deskriptif untuk analisis data. Hasil penelitian menunjukkan bahwa ikan baronang tersebut hanya satu spesies dan diduga terdiri dari tiga varian. Keiga varian ikan memiliki gen $12 \mathrm{~S}$ rRNA yang sama dengan ukuran fragmen sekitar1000 base pairs (bp). Klasifikasi morfologi tiga kelompok ikan tidak menunjukkan jumlah spesies, melainkan tidak lebih sebagai varian genetik.
\end{abstract}

Kata kunci: ikan baronang; morfologi; gen 12S; varian genetic; PCR

\begin{abstract}
This study aims to obtain the certainty of the number of species of baronang fish (Siganus spp.) Siganidae family in the waters of the south sea of Lombok Island. This study used a sample of 90 fish from the fishermen's catch. Sampling used a random method three times. Observation of morphological characters used 90 and nine fishes for molecular characters-12S rRNA genes. The study used a descriptive technique for data analysis. The results showed that the fish is only one species and suspected consists of 3 variants. Three variants of fish have the same 12S rRNA genes with a fragment size of approximately $1000 \mathrm{bp}$. The morphological classification of the three groups of fish does not indicate the number of species, but no more as genetic variants.
\end{abstract}

Keyword: baronang fish; morphology;12S gene; genetic variants; PCR 


\section{PENDAHULUAN}

Ikan baronang merupakan salah satu jenis ikan ekonomis penting, menjadikan ikan ini sebagai salah satu target utama penangkapan. Salah satu alasan ikan baronang disebut sebagai ikan ekonomis penting adalah memiliki kandungan asam lemak omega-3 atau lebih populer disebut dengan Omega-3, sangat bermanfaat dalam pencegahan penyakit jantung koroner, diabetes, kanker, dan berperan penting dalam sistem syaraf, otak dan mata (Sayanova et al., 2011; Calder, 2012; Suseno et al., 2014; Nabavi et al., 2015). Potensi ikan baronang di perairan Indonesia cukup potensial, terutama keberadaannya di perairan dangkal seperti ekosistem terumbu karang dan padang lamun. Selain ikan baronang memiliki nilai ekonomis tinggi, penangkapannya tidak terlalu sulit sehingga ikan baronang ini mengalami tangkap lebih (over fishing). Stok ikan baronang di alam tidak dapat diandalkan untuk memenuhi permintaan masyarakat dari waktu ke waktu mengalami peningkatan, sehingga kegiatan budidaya sudah mulai banyak dikembangkan sebagai solusinya (Kune, 2007).

Ghufron dan Kordi (2005) melaporkan bahwa terdapat 12 spesies ikan baronang di perairan laut Indonesia namun yang dibudidaya oleh para petani pada umumnya hanya 5 spesies yaitu: Siganus guttatus, S. canaliculatus, S. javus, S. vermiculatus dan S. virgatus. Selanjutnya dikatakan bahwa $S$. javus dan $S$. vermiculatus umumnya hidup di sekitar perairan yang berhutan bakau, pelabuhan, dan kadang-kadang masuk dalam sungai serta danau. Ikan baronang tersebesar di perairan laut Indo-Pasifik dan perairan Timur Mediterania (Randall et al., 1997; Musaiger dan D'souza, 2011). Klasifikasi ikan baronang menurut Kuiter dan Tonozuka (2001) sebagai berikut: Kingdom: Animalia; Filum: Chordata; Kelas: Pisces; Sub kelas: Teleostei; Ordo: Perciformes; Famili: Siganidae; Genus: Siganus. Lam (1974) melaporkan bahwa ikan baronang hidup pada daerah berkarang, dasar perairan berpasir dan banyak ditumbuhi rumput laut. Berdasarkan ciri-ciri habitat tersebut, ikan baronang memiliki potensi dan peluang budidaya yang cukup potensal di perairan pesisir dan laut pulau Lombok karena didukung oleh kondisi lingkungan perairan yang sesuai dan di sepanjang perairan pesisir dan laut selatan Lombok terjadi penaikan masa air (upwelling) yang menyebabkan perairan menjadi subur (Hendrawan dan Asai, 2011).

Pada dasarnya ikan baronang dapat dikenal dengan mudah karena bentuknya khas seperti kepalanya berbentuk mirip kelinci, sehingga ikan ini disebut juga dengan nama rabbit fish (Woodland, 1990). Ciri-ciri khusus ikan baronang adalah bentuk tubuh oval sampai lonjong, pipih, tinggi sampai ramping serta ditutupi oleh sisik-sisik yang kecil dan halus, mulut kecil dengan posisi terminal dan rahangnya dilengkapi dengan gigi-gigi kecil (Woodland, 1990; Tarwijah, 2001). Karakter morfologi ikan baronang tersebut telah lama menjadi acuan identifikasi, pemetaan kekerabatan dan taksonomi ikan, namun karakter morfologi ini dinilai terbatas karena langsung dipengaruhi oleh faktor lingkungan.

Identifikasi spesies mahluk hidup berdasarkan karakter morfologi memiliki banyak kelemahan karena banyaknya kemiripan antar spesies dan ciri khas penting untuk diagnosa seringkali menghilang sebagai akibat dari adaptasi terhadap lingkungan (Prehadi et al., 2015). Berbeda halnya dengan penanda (marker) molekuler memiliki hasil identifikasi yang lebih stabil dibandingkan dengan penggunaan karakter morfologi, sebab marker molekuler ditentukan langsung oleh materi genetik (DNA).Karakter molekuler yang banyakdigunakan 
pada hewan ialah DNA gen 12S rRNA, gen Cytokrom Oxidase Subunit 1 (COX1), dan 16S rRNA (Wong et al., 2004; Barr et al., 2006; Ratnasingham dan Hebert, 2007; Gupta et al., 2008; Ferri et al., 2009).

Gen 12S rRNA memiliki daerah coding dari 37 gen pada DNA mitokondria (mtDNA) yang sangat homolog tetapi memiliki banyak variasi untuk tiap spesies (Dalmasso et al., 2004; Ioja-Boldura et al., 2011; Sakalar dan Abasiyanik, 2011). Daerah mitokondria dikenal mengalami perubahan cepat dalam evolusi. Di samping itu DNA mitokondria gen 12S rRNA merupakan alat yang kuat dalam mempelajari evolusi hewan dan juga banyak digunakan untuk identifikasi, analisis struktur populasi, aliran gen, dan filogeni (Moritz, 1999). Identifikasi spesies ikan baronang berdasarkan pendekatan marker molekuler belum banyak terungkap, sedangkan identifikasi secara morfologi seringkali menimbulkan kesalahan karena banyaknya kemiripan antar spesies, oleh karena itu studi identifikasi spesies ikan baronang secara morfologi dan molekuler menggunakan gen 12S rRNA penting dilakukan untuk memastikan spesies ikan baronang.

\section{Lokasi pengambilan sampel}

\section{BAHAN DAN METODE}

Penelitian dilaksanakan pada bulan Agustus sampai bulan November 2017. Pengambilan sampel ikan baronang di perairan laut selatan pulau Lombok pada tiga stasiun (Gambar 1). Ikan baronang adalah ikan ekonomis peniting yang memiliki potensi bibit paling tinggi di lokasi studi (Syukur et al., 2016).

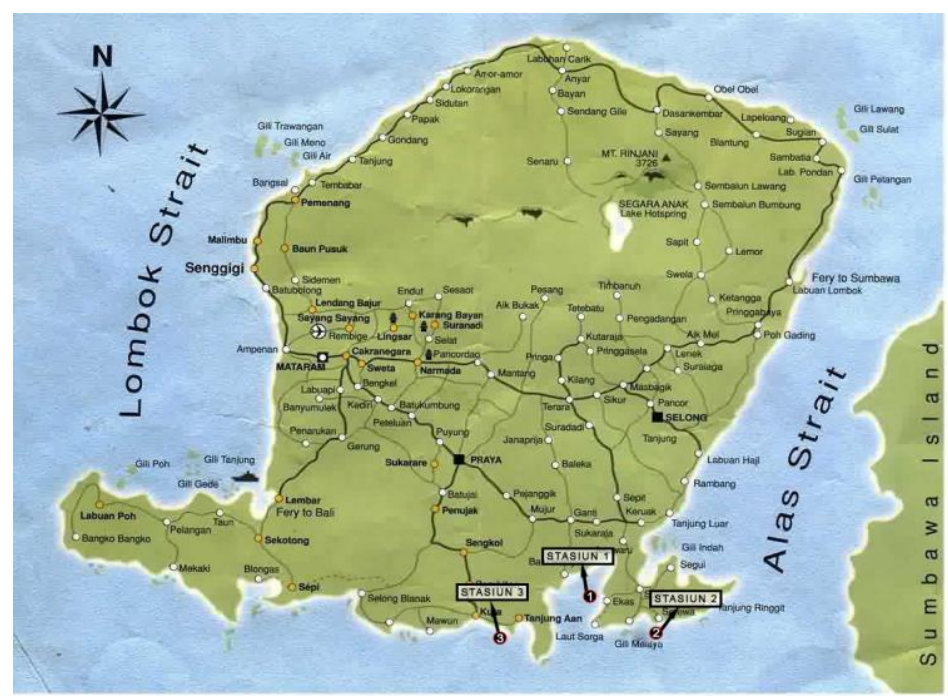

Gambar 1. Lokasi pengambilan sampel di tiga stasiun

Ket: Stasiun 1: 8'51'22.62" LS dan 116²7'11.99” BT. Stasiun 2: 855'39.77” LS dan 116³0'18.58” BT. Stasiun 3: 86'16.91” LS dan 116²19'53.26” BT).

\section{Identifikasi berdasarkan karakter morfologi}

Sampel ikan baronang sebanyak 90 ekor yang sudah di grouping (dikelompok) di lapangan menggunakan karakter morfologi seperti bentuk kepala, tubuh, dan sisik. Selanutnya 
ikan baronang sampel dibawa ke Laboratorium Pendiikan IPA FKIP Universitas Mataram untuk diidentifikasi berdasarkan karakter morfologi (morfometrik \& meristik). Metode yang digunakan untuk mengidentiikasi ikan baronang adalah modifikasi dari metode Samonte et $a l .$, (2009) berdasarkan karakter morfometrik dan meristik. Menurut Muhiddin (2010), karakter morfometrik berperan lebih besar dalam membedakan kelompok-kelompok kawanan ikan dan menjadi pembeda antara kelompok satu dengan kelompok lainnya. Karakter morfometrik yang dianalisis adalah panjang standard, panjang kepala, dan lebar tubuh, sedangkan karakter meristik meliputi jumlah duri pada punggung dari depan ke belakang, dan bentuk sirip punggung dari depan ke belangang.

\section{Ekstraksi dan amplifikasi DNA gen $12 S$ rRNA}

Ekstraksi dan amplifikasi DNA gen 12S rRNA ikan baronang dilakukan di Laboratorium Bio Medik Rumh Sakit Umum Daerah Provinsi Nusa Tenggara Barat. Metode yang digunakan untuk ekstraksi DNA adalah modifikasi dari metode yang dilakukan oleh Ariyanti dan Sianturi (2019). Sampel diambil dari bagian daging sembilan ekor ikan baronang masing-masing sebanyak 30 gram. Jaringan diambil dengan scalpel steril. Ekstraksi DNA dari jaringan daging ikan baronang dilakukan menggunakan reagen DNAzol (Invitrogen). Daging ikan dihaluskan dan ditambahkan 200 uL DNAZol, dikocok bolak balik 10 kali dan dikocok (vorteks) $200 \mathrm{rpm}$ selama dua menit. Sampel disentrifius 10.000 rpm selama 10 menit, supernatan dipindahkan pada tabung baru yang steril. Supernatan ditambahkan etanol obsolut 200 ul, diinkubasi pada suhu ruangan selama tiga menit, kemudian disentrifugasi $800 \mathrm{rpm}$ selama 2 menit untuk mendapatkan DNA total.

DNA hasil ekstraksi diamplifikasi dengan metode PCR (Polymerase Chain Reaction) menggunakan kit Maxime PCR PreMix Kit (iNtRON). Sepasang primer dari DNA mitokondria gen $12 \mathrm{~S}$ rRNA telah dirancang dan dipilih untuk mengamplifikasi spesifisitasnya, menggunakan primer forward: 5'-GCTTGGTCCTGACTTTAGTA-3', dan primer reverse: 5'CTTACCATGTT-ACGACTTGC-3' (Mahrus et al., 2012). Gen 12S rRNA dan beberapa gen laiinnya seperti COX1, dan ND4L merupakan salah satu daerah unik yang terdapat pada genom mitokondria dan umumnya digunakan untuk studi filogenetik dan identifikasi spesies (Hou et al., 2006; Baaka, 2013; Singh et al., 2015). PCR dilakukan dalam $25 \mu \mathrm{L}$ reaksi yang terdiri dari $1 \mu \mathrm{L}$ DNA hasil ekstraksi, 2,5 $\mu \mathrm{L}$ 10x PCR buffer (Applied Biosystems), 2,5 $\mu \mathrm{L} 10$ mMdNTPs, masing-masing 1,25 $\mu \mathrm{L}$ primer dengan konsentrasi $10 \mathrm{mM}, 2 \mu \mathrm{L} 25 \mathrm{mM} \mathrm{MgCl} 2$, 0,125 $\mu \mathrm{L}$ AmplyTaq ${ }^{\mathrm{TM}}$ (Applied Biosystems) dan 14,5 $\mu \mathrm{L}$ ddH2O (Yusmalinda et al., 2017). Reaksi dilakukan dalam 38 siklus menggunakan teknik "Hotstart" dengan parameter sebagai berikut: predenaturasi dilakukan pada suhu $80 \mathrm{oC}$ selama 10 detik dan $94^{\circ} \mathrm{C}$ selama 15 detik, kemudian dilanjutkan dengan tahap denaturasi pada suhu $94^{\circ} \mathrm{C}$ (30 detik), penempelan primer atau annealing pada suhu 50oC (30 detik), pemanjangan rantai nukleotida atau extension selama 45 detik pada suhu $72 \mathrm{oC}$ dan siklus pemanjangan untai ganda di akhir amplifikasi selama 5 menit pada suhu 720 . Hasil reaksi PCR kemudian divisualisasi dalam 1,2\% gel agarose yang ditambahkan dengan ethidium bromide. Untai DNA yang dihasilkan dalam reaksi PCR akan berpendar di bawah sinar UV karena ethidium bromide dapat berikatan dengan 
DNA. Hasilnya diamati dengan alat visualisasi Biorad Gel Doc XR tipe $170-8170$ yang dilengkapi komputer dengan software Quantity One (Biorad, USA).

\section{HASIL DAN PEMBAHASAN}

Ikan baronang berdasarkan karakter morfologi

Dari 90 ekor ikan baronang tersebut, ternyata ikan baronang terdiri dari tiga kelompok (group) berdasarkan karakter morfologi (Gambar 2). Kelompok 1 sebanyak 36 ekor (40\%), kelompok 2 berjumlah 29 ekor (32\%), dan sisanya 25 ekor (28\%) sebagai kelompok 3.

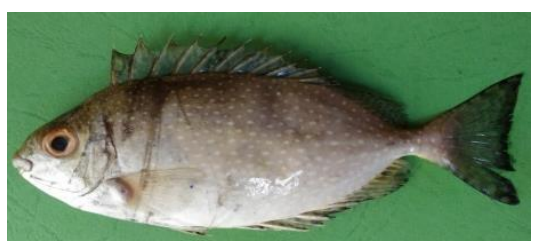

Kelompok 1

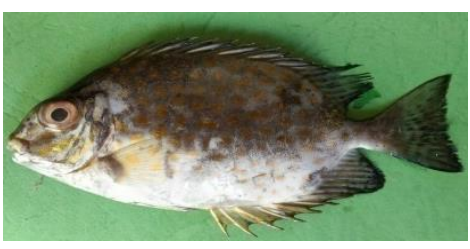

Kelompok 2

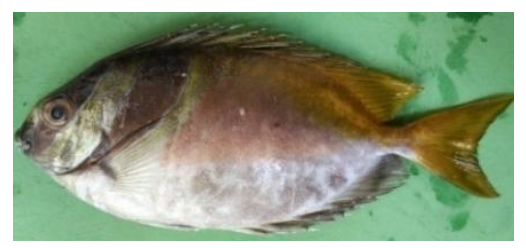

Kelompok 3

Gambar 2. Ikan baronang berdasarkan karakter morfologi

Hasil penelitian ini hampir sama dengan yang dilaporkan oleh Mahrus et al. (20018), memiliki sedikit perbedaan antara kelompok ikan baronang. Pada kelompok 1 memiliki ciri morfologi sebagai berikut: kepala berbentuk sedikit cekung, dibagian atas mata terdapat sebuah lipatan kecil berwarna gelap, bentuk badan pipih dan ramping ditutupi oleh sisik ber ukuran kecil dan tipis, punggung berwarna sedikit coklat, perut berwarna silver, terdapat bintik berbentuk seperti garis berwarna gelap pada sirip punggung, dubur dan ekor; sirip perut memiliki tiga jari lunak; sirip punggung dengan 13 duri yang keras dan 10 jari lunak, dan pada sirip anal (dubur) terdapat sembilan jari lunak dan tujuh duri yang tajam, memiliki kelenjar racun yang berfungsi untuk mempertahkan diri dari musuh. Fungsi sirip anal/dubur adalah sebagai penyeimbang saat ikan berenang. Semua ciri-ciri pada kelompok 1 ini minimal dimiliki oleh ketiga kelompok ikan baronang. Ciri morfologi ikan baronang tersebut hampir sama dengan ciri spesies $S$. canaliculatus seperti yang dilaporkan oleh beberapa peneliti (Woodland, 1990; Tarwijah, 2001; Sahabuddin et al., 2015).

Kelompok 2 ikan baronang memiliki ciri morfologi hampir sama dengan ikan baronang di kelompok 1. Keduanya memiliki bentuk tubuh mirip yaitu tubuh oval hingga lonjong, pipih, tinggi dan ramping. Tubuhnya ditutupi sisik yang kecil dan memanjang, mulutnya kecil dengan posisi terminal dilengkapi gigi-gigi yang yang kecil dan ramping. Perbedaan antar keduanya tubuh bagian atas berwarna abu-abu kebiruan, sedangkan bagian bawah berwarna perak dengan bintik-bintik yang lebih besar berwarna kuning keemasan. Pada bagian bawah sirip punggung belakang terdapat sebuah bintik besar berwarna kuning keemasan. Ciri-ciri morfologi ikan baronang ini hamper sama dengan ciri-ciri yang terdapat pada S. guttatus, sering disebut dengan Rabbit fish dengan alasan bentuk kepalanya mirip kepala kelinci (Woodland, 1990; Ghufron dan Kordi, 2005; Hamka, 2006). 
Ikan baronang yang dimasukkan pada kelompok 3 memiliki perbedaan sangat sedikit dengan kedua kelompok ikan sebelumnya, terdapat pada warna tubuh yaitu berwarna kecoklatan, terdapat 8-10 bintik-bintik berwarna silver dan sedikit oranye, gurat sisi sedikit berwarna gelap, dada bersisik tetapi tidak sampai panggul. Ciri morfologi ikan baronang ini mirip dengan S. punctatus seperti yang dilaporkan oleh Burhanuddin et al. (2014). Hasil penelitian sebelumnya melaporkan bahwa $S$. punctatus di Great Barrier Reef selatan Australia berbeda dari kebanyakan spesies ikan baronang lainnya yaitu memiliki vesikula seminalis yang hampir selalu seluruhnya ada di belakang (Bray \& Cribb, 2001).

Marker molekuler DNA gen 12S rRNA ikan baronang

Fragment DNA gen $12 \mathrm{~S}$ rRNA ketiga kelompok ikan baronng yang didapatkan dari hasil amplifikasi menggunakan metode PCR memiliki panjang yang hampir sama yaitu sekitar 1000 bp (Gambar 3). Berdasarkan ukuran DNA gen 12S rRNA tersebut, tampak bahwa ikan baronang yang tertangkap dari perairan laut selatan pulau Lombok tidak menunjukkan perbedaan di antara ketiga kelompok. Hal ini berarti bahwa ketiga kelompok ikan baronang tersebut tidak menunjukkan spesies yang berbeda tetapi lebih memperlihatkan adanya variasi genetik dalam satu spesies yaitu $S$. canaliculatus. Hasil penelitian ini berbeda dengan beberapa hasil penelitian yang dilaporkan oleh beberapa peneliti sebelumnya. Tang et al. (1999) melaporkan fragmen gen 12S ikan baronang (S. canaliculatus) dari perairan Indo-Pasifik Barat dan Mediterania lebih pendek (814 bp) dibandingkan dengan hasil penelitian ini (1000 bp).

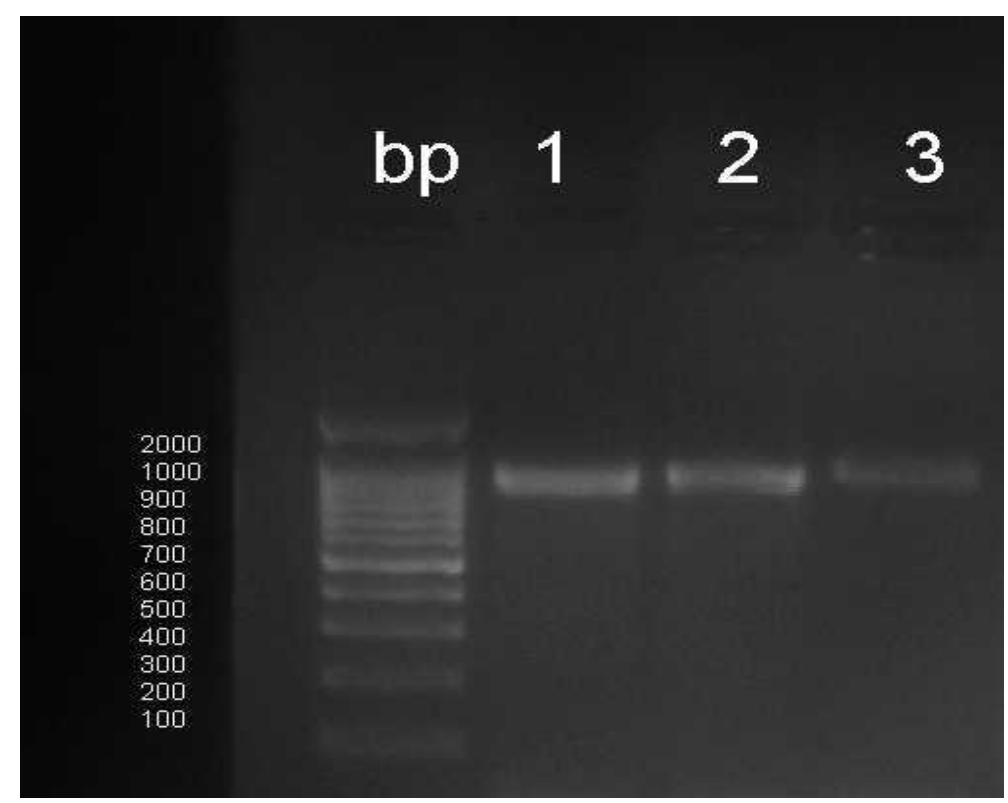

Gambar 3. Hasil amplifikasi DNA ikan Baronang

Ket: 1, 2, dan 3 adalah kelompok ikan baronang

Hasil penelitian berbeda lainnya adalah Woodland dan Anderson (2014) berhasil membedakan 2 spesies baronang baru yang memiliki karakter morfologi sangat mirip dengan menggunakan pendekatan warna tubuh dan sekuens gen sitokrom $b$ dan gen $12 \mathrm{~S}$ rRNA. Kedua spesies baronang tersebut adalah: $S$. insomnis dari Maladewa dan India bagian selatan, dan $S$. 
lieatus (Valenciennes) dari Pasifik Barat. Bray dan Cribb (2001) melaporkan bahwa S. punctatus dan S. lineatus di lepas Pulau Heron-Great Barrier Reef selatan Australia berbeda dari kebanyakan spesies lain yang memiliki vesikula seminalis yang hampir selalu seluruhnya ada di belakang. Mahrus et al. (2012) melaporkan hasil analisisnya yang ditampilkan pada pohon filogenetik dari 11 spesies ikan laut ekonomis penting menggunakan sekuens Gen $12 \mathrm{~S}$ rRNA yang diakses dari data geneBank (Gambar 4), tampak bahwa ikan baronang ( $S$. canaliculatus) berada satu kelompok dengan Sparatus aurata padahal keduanya berasal dari family dan genus yang berbeda. Sparatus aurata berasal dari family Sparidae dan genus Sparus, sedangkan ikan baronag dari Family Siganide dan Genus Siganus.

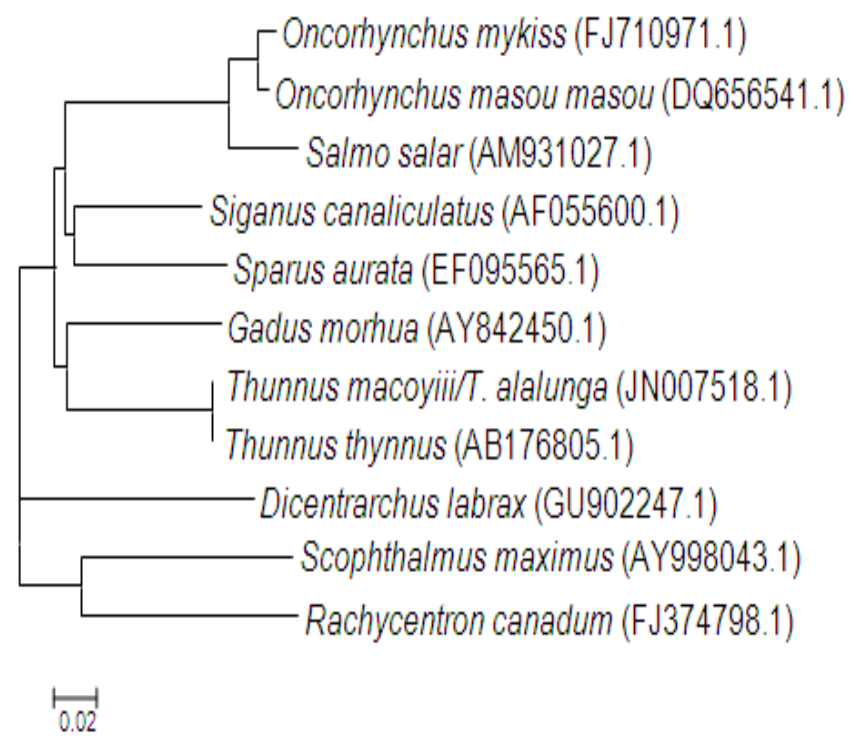

Gambar 4. Filogenetik 11 spesies ikan laut ekonomis penting berdasarkan sekuens DNA gen $12 \mathrm{~S}$ rRNA yang diakses dari GenBank (Mahrus et al., 2012)

Marengo et al (2014) menjelaskan karakter morfologi Sparatus aurata memiliki bentuk tubuh oval, agak dalam dan pipih, profil kepala melengkung secara teratur, mata kecil, mulut rendah, sangat sedikit miring, bibirnya tebal, terdapat empat hingga enam gigi mirip taring di bagian anterior di setiap rahang diikuti posterior dengan gigi tumpul yang menjadi seperti molar progresif dan disusun dalam dua hingga empat baris serta gigi pada dua baris luar lebih kuat. S. canaliculatus dan Sparatus aurata pada Gambar 4 sesungguhnya menjelaskan bahwa kedua spesies ikan tersebut memiliki hubungan kekerabatan yang sangat dekat, artinya dari sisi genetika kedua ikan tersebut adalah satu spesies. Jika dia satu spesies maka tentu memiliki nama yang sama, namun faktanya berbeda. Fenomena ini menginformasikan bahwa karakter morfologi tidak signifikan untuk mengidentiikasi spesies ikan baronang dan berbagai spesies ikan lainnya. Hasil-hasil penelitian tersebut menunjukkan bahwa karakter morfologi tidak cukup kuat untuk membedakan satu spesies ikan baronang dengan spesies baronang lainnya. 


\section{KESIMPULAN}

Ikan baronang yang tertangkap dari perairan laut selatan pulau Lombok berdasarkan karakter morfologi dan molekuler dengan menggunakan marker DNA gen 12S rRNA tidak menunjukkan jumlah spesies karena memiliki panjang fragment DNA gen 12S rRNA sama. Hal ini berarti bahwa ikan baronang yang tertangkap di perairan laut selatan pulau Lombok hanya satu speies yang terdiri dari beberapa varian genetik.

\section{Ucapan Terima Kasih}

Tim peneliti mengucapkan terima kasih kepada Kementrian Riset dan Teknologi yang memberikan dana penelitian melalui Skim Penelitian Dasar Unggulan Perguruan Tinggi Tahan Anggran 2017.

\section{DAFTAR PUSTAKA}

Ariyanti, Y., and Sianturi, S. 2019. Ekstraksi DNA total dari sumber jaringan hewan (Ikan Kerapu) menggunakan metode kit for animal tissue. Journal of Science and Applicative Technology, 3(1), 40-45.

Baaka, A. 2013. Kajian keragaman genetik gen Cytochrome Oxidase SubUnit 1 (COX1) Tarsius sp. sebagai upaya penentuan asal usul Tarsius sp (Doctoral dissertation, Universitas Gadjah Mada).

Barr, N.B., Copeland, R.S., De Meyer, M., Masiga, D., Kibogo, H.G., Billah, M.K., Osir, E., Wharton, R.A., and McPheron, B.A. 2006. Diagnostik molekuler ekonomis penting spesies lalat buah Ceratitis (Diptera: Tephritidae) di Afrika menggunakan analisis PCR dan RFLP. Bull Entomol Res., 96: 505-521.

Bray, R. A., and Cribb, T. H. 2001. Lecithophyllum kitrii n. sp.(Digenea: Lecithasteridae) from Australian coral reef fishes of the genus Siganus. Systematic parasitology, 50(2), 143147.

Burhanuddin, A. I., Budimawan and Sahabuddin. 2014. The Rabbit-Fishes (Family Siganidae) from The Coast of Sulawesi, Indonesia. International Journal of plant, animal and environmental sciences, 4(4): 95-102.

Calder, P. C. 2012. The role of marine omega-3 (n-3) fatty acids in inflammatory processes, atherosclerosis and plaque stability. Mol Nutr Food Res 56:1073-1080

Dalmasso, A., Fontanella, E., Piatti, P., Civera, T., Rosati, S., and Bottero, M. T. 2004. A multiplex PCR assay for the identification of animal species in feedstuffs. Molecular and cellular probes, 18(2), 81-87.

Ferri, G., Alù, M., Corradini, B., Licata, M., and Beduschi, G. 2009. Spesies identifikasi melalui DNA "barcode". Biomarker Genet Mol Test., 13: 421-6.

Ghufron. M., and Kordi, H. 2005. Budidaya Ikan Laut di Keramba Jaring Apung. Penerbit Rineka Cipta, Jakarta.

Gupta, A.R., Patra, R.C., Das, D.K., Gupta, P.K., Swarup, D., and Saini, M. 2008. Sequence karakterisasi dan polymerase chain reaction-pembatasan Polimorfisme panjang fragmen gen 12S rRNA DNA mitokondria menyediakan metode untuk identifikasi spesies rusa India. DNA mitokondria, 19: 394-400. 
Hamka. 2006. Upaya Pematangan Gonad Ikan Baronang (Siganus guttatus) Melalui Pemberian Pakan Buatan dan Pakan Alami (Gracillaria sp.) pada Bak Terkontrol. Laporan Tahunan. Balai Budidaya Air Payau Takalar.

Hendrawan, I. G and Asai, K. 2011. Numerical Study of Tidal Upwelling Over The Sill In The Lombok Strait (Indonesia). In: Proceedings of the Twenty-first (2011) International Offshore and Polar Engineering Conference. Maui, Hawaii, USA: the International Society of Offshore and Polar Engineers (ISOPE); 949-956.

Hou, W., Y. Chen, X. Wu, J. Hu, Z. Peng, J. Yang, Z. Tang, C. Zhou, Y. Li, S. Yang, Y. Du, L. Kong, Z. Ren, H. Zhang and S. Shui. 2006. A Complete Mitochondrial Genome sequence of Asian Black bear Sichuan Subspecies (Ursus thibetanus mupinensis). Int. J. Biol. Sci. 3(2):85-90.

Ioja-Boldura, O. M., Popescu, S., Bruznican, S., and Hutu, I. 2011. Applicability of a multiplex PCR assay for the identification of animal species in feedstuffs. Bulletin of University of Agricultural Sciences and Veterinary Medicine Cluj-Napoca. Animal Science and Biotechnologies, 68(1-2).

Kuiter, R.H., and Tonozuka, T. 2001. Indonesian reef fishes. Part 2. Fusiliers to dragonets: Caesionidae to Callyonimidae. Zoonetic, Melbourne. Australia. 161p.

Kune, S. 2007. Pertumbuhan rumput laut yang dibudidaya bersama ikan Baronang. Jurnal Agrisistem, 3(1), 7-9.

Lam, T. J. 1974. Siganid. Their biology and mariculture potential. Aquaculture (3). Pp. 324354.

Mahrus, Zulkifli, L., and Karnan. 2018. Keragaman genetik ikan baronang (Siganus spp.) berdasarkan gen $12 \mathrm{~S}$ rRNA dari perairan laut selatan pulau Lombok. Prosiding Seminar Nasional Pertanian, Faperta Unram, Mataram, 29 November 2018.

Mahrus, Sumitro, S. B., Utomo, D. H., Sartimbul, A., Toha, A. H., and Widodo, N. 2012. Genetic relationship of Sardinella lemuru from Lombok Strait with fish rich in omega3 fatty acid. Bioinformation, 8 (25): 1271-1276.

Marengo, M., Durieux, E. D., Marchand, B., and Francour, P. 2014. A review of biology, fisheries and population structure of Dentex dentex (Sparidae). Reviews in fish biology and fisheries, 24(4), 1065-1088.

Moritz, C. 1999. Conservation units and translocations: strategies for conserving evolutionary processes. Hereditas, 130(3), 217-228

Muhiddin, A. H. 2010. Identifikasi dan klasifikasi kawanan lemuru Selat Bali berdasarkan data hidroakustik dengan metode statistik. Torani (Jurnal Ilmu Kelautan dan Perikanan), 20 (1): 25-36.

Musaiger, A.O and D'Souza, R. 2011. Fatty acid profile of raw and cooked fish consumed in Bahrain. African Journal of Food Science, 5(4): 213 - 218.

Nabavi, S. F., Bilotto, S., Russo, G. L., Orhan, I. E., Habtemariam, S., Daglia, M., and Nabavi, S. M. (2015). Omega-3 polyunsaturated fatty acids and cancer: lessons learned from clinical trials. Cancer and Metastasis Reviews, 34(3), 359-380.

Prehadi, P., Sembiring, A., Kurniasih, E. M., Rahmad, R., arafat, D., Subhan, B., and Madduppa, H. H. 2015. DNA barcoding and phylogenetic reconstruction of shark 
species landed in Muncar fisheries landing site in comparison with Southern Java fishing port. Biodiversitas Journal of Biological Diversity, 16(1).

Randall, J. E., G. R., Allen, R. C., and Steene. 1997. Fishes of the Great Barrier Reef and Coral Sea. University of Hawaii Press, Honolulu, HI, 507 p.

Ratnasingham, S., and Hebert, P.D.N. 2007. BOLD: The Life Barcode Sistem Data. Mol Ecol., 7: 355-364.

Sahabuddin, I. Burhanuddin, A. C. Malina and Nurhapsa. 2015. Morfometrik dan meristik ikan baronang (Siganus canaliculatus Park, 1797) di perairan teluk Bone dan selat Makassar. Torani (Jurnal Ilmu Kelautan dan Perikanan), 25(1): 44-52.

Sakalar, E., and Abasiyanik, M. F. 2011. Qualitative analysis of meat and meat products by multiplex polymerase chain reaction (PCR) technique. African Journal of Biotechnology, 10(46), 9379-9386.

Samonte, I., Canlas, R., Alvia, K., Carvajal, T., and Pagulayan, R. 2009. Multivariate analyses of the biometric features from Philippine sardines-implications for the phylogenetic relationships of the freshwater Sardinella tawilis (Teleostei, Clupeomorpha). J Zool Syst Evol Res., 47(1): 21-24.

Sayanova, O., Haslam, R. P., Calerón, M. V., López, N. R., Worthy, C., Rooks, P., ... and Napier, J. A. 2011. Identification and functional characterisation of genes encoding the omega-3 polyunsaturated fatty acid biosynthetic pathway from the coccolithophore Emiliania huxleyi. Phytochemistry, 72(7), 594-600. Emiliania huxleyi. Phytochemistry, 72(7): 594-600.

Singh, D., Khullar, N., and Jha, C. 2015. Lucrative potentials of mitochondrial DNA: A laconic review accentuating particularly blow flies beyond forensic importance. Journal of Entomology and Zoology Studies, 3(4): 01-08.

Suseno, S.H., Tambunan, J.E., Ibrahim, B and Saraswati. 2014. Inventory and Characterization of Sardine (Sardinella sp.) Oil from Java Island-Indonesia. Advance Journal of Food Science and Technology, 6(5): 588-592.

Syukur, A., Mahrus. and Sychrudin . A. 2016. The potential assessment environment friendly aquaculture of small-scale fishermen as a conservation strategy seagrass beds in coastal areas of Tanjung Luar East Lombok, Indonesia.

Tang, K.L., Berendzen, ,P. B., Wiley, E. O., Morrissey, J. F., Winterbottom, R., and Johnson, G. D. 1999. The phylogenetic relationships of the suborder Acanthuroidei (Teleostei: Perciformes) based on molecular and morphological evidence. Mol. Phylogenet. Evol. 11 (3), 415-425. PUBMED 10196082.

Tarwijah. 2001. Pembenihan Ikan Baronang (Siganus sp). Booklet Jenis-Jenis Komoditi Laut Ekonomis Penting Pada Usaha Pembenihan. Direktorat Bina Pembenihan, Dirjen Perikanan, Departemen Pertanian, Jakarta.

Wong, K.L., Wang. J., Tapi, P.P.H., and Shaw, P.C. 2004. Aplikasi urutan DNA ctyochrome b untuk otentikasi spesies ular terancam punah. Forensic Sci Int., 139: 49-55.

Woodland, D. J and Anderson, R. C. 1990. Description of a new species of rabbitfish (Perciformes: Siganidae) from southern India, Sri Lanka and the Maldives. Zootaxa, 3811 (1): 129-136. 
Woodland, D. J. 1990. Revision of the fish family Siganidae with descriptions of two new species and comments on distribution and biology. Indo-Pacific Fishes, 19.

Yusmalinda, N. L. A., Aji, W., Dio, M. S., I Made J. R., Dwi, S., Danielle, K, and Ni Kadek,D. C. 2017. Identifikasi jenis pada kejadian cetacea terdampar di Indonesia dengan teknik molekuler. Jurnal Ilmu dan Teknologi Kelautan Tropis, 9 (2): 465-474. 